ISSN 0258-7122

Bangladesh J. Agril. Res. 37(1): 19-25, March 2012

\title{
INFESTATION AND MANAGEMENT OF THE LEAF ROLLER (Lamprosema indicata Fab.) IN SOYBEAN (Glycine max L.)
}

\author{
G. C. BISWAS ${ }^{1}$ AND RABIUL ISLAM ${ }^{2}$
}

\begin{abstract}
Infestation and management of leaf roller of soybean were studied in the field and laboratory of the Oilseed Research Centre (ORC), Bangladesh Agricultural Research Institute (BARI), Joydebpur, Gazipur during the rabi seasons of 200708 and 2008-09. Leaf roller infestation was observed in the 3rd week of January at the vegetative and flowering stages (45-60 days after sowing=DAS) of the crop and continued up to pre-maturity period (80-85 DAS). The highest leaf roller population (0.9 and 1.00/plant in 2008 and 2009, respectively) and infestation (90\% plant in 2008 and 95\% plant in 2009) were recorded in the last week of February at the pod formation stage of the crop (65-70 DAS). Among the treatments, hand picking technique reduced the highest plant and leaf (98\%) infestation. The highest seed yield (1300 kg/ha) was obtained from Diazinon 60 EC treated plots, followed by hand picking+neem seed extract treated plot (1280 $\mathrm{kg} / \mathrm{ha}$ ). The highest BCR (3.00) was obtained from the hand picking technique plots followed by Diazinon 60 EC treated plots (2.66).
\end{abstract}

Keywords: Soybean, leaf roller, handpicking, neem seed extract.

\section{Introduction}

In Bangladesh, soybean (Glycine max L.) is cultivated both in the rabi and kharif seasons. Soybean contains about $42 \%$ protein and $20 \%$ oil (Fehr, 1989). Although soybean oil is very popular as a cooking, cultivation of soybean is comparatively new in Bangladesh. Recently the crop has gained popularity in the poultry industry and its cultivation area is gradually increasing that covers about 40,000 ha in Noakhali and Laxmipur Districts (Anonymous, 2009). Soybean can contribute significantly to meet the nutrition requirement of the people in Bangladesh (Biswas, 2001). Fifty seven species of insects are found to attack the soybean crop at different growth stages in Bangladesh (Biswas, 2008). Among these, the leaf roller Lamprosema indicata Fab. has appeared as the most damaging pest in recent years (Das, 1998; Biswas et al., 2001, Biswas, 2008). The insect is found in India, Thailand, the Philippines and other countries of Asia (Sachan and Gangwar, 1980). In addition to soybean crop, it also infests beans, cowpea, green gram, black gram and red gram (Nair, 1986). The adult moth is creamy yellow to light brown with oblique wavy black lines on both pairs of

${ }^{1}$ Senior Scientific Officer, Oilseed Research Centre (ORC), Bangladesh Agricultural Research Institute (BARI), Gazipur-1701, ${ }^{2}$ Scientific Officer, ORC, BARI, Gazipur-1701, Bangladesh. 
wings. Females lay about 400 eggs in batches of 10-20 on the young leaves. Hatching out from the eggs in a week, the young larvae feed on the epidermal layer of the leaves. The larvae roll the leaves from tip downwards and then feed inside the young leaves and buds. Damaged leaves have a silvery-brown papery look and are noticeable from a distance (Biswas et. al., 2001). Dependence of the farmers of Noakhali region solely on the use of chemical insecticides for controlling the pests has posed a number of potential problems that include resistance of the pest, destruction of beneficial organisms and environmental pollution (McIntyre et al., 1989). Botanicals are less toxic, naturally available materials, less expensive, and also safe for beneficial organisms. Neem products containing azadirachtin, salanin and meliontriol have been found to be effective for controlling different insect pests (Saxena et al., 1981, Haque and Islam, 1988). The neem products also act as repellent to the insect and thus reduce insect infestation (Sarode et al., 1995). There is a need to integrate different control approaches to achieve better results without less bad effects on environment. Information regarding this insect and its management are scanty in this country. Therefore, the study was undertaken to record incidence patterns, infestation rates, yield loss and management of the pest in soybean.

\section{Materials and Method}

The experiment was conducted in the field and laboratory of Oilseed Research Centre (ORC) of Bangladesh Agricultural Research Institute (BARI) at Gazipur for two consecutive years (2007-08 and 2008-09) during December to April. Seeds of BARI Soybean-5 were sown in the 3rd week of December in both the years in $3 \mathrm{~m} \times 4 \mathrm{~m}$ plots following a RCB design with 3 replications. Application of fertilizers and intercultural operations were done as recommended by Hossain (2008). The rows and plants were spaced $40 \mathrm{~cm} \times 5 \mathrm{~cm}$. Seven treatments, namely $\mathrm{T}_{1}=$ Hand picking of infested leaves with larvae; $\mathrm{T}_{2}=$ Spraying of neem seed kernel extract (NSKE); $\mathrm{T}_{3}=$ Hand picking $+\mathrm{NSKE} ; \mathrm{T}_{4}=$ Spraying of Diazinon60 EC @ 2ml/l of water; $\mathrm{T}_{5}=$ Dursban 20 EC @ 2ml/l of water; $\mathrm{T}_{6}=$ Perfekthion 40EC @ 2ml/l of water, and $\mathrm{T}_{7}==$ untreated control were tested. Hand picking of infested leaves with larvae was started from initial stage of infestation at the vegetative, flowering, and pod formation stages at 15 days intervals. Five hundred grams (500 g) neem seed kernel were crushed and soaked over night in 10 litres of water and strained through a fine net. Neem seed extract and chemical insecticides were applied three times starting from the second week of February to second week of March at 15-day intervals. Leaf roller infestation was recorded regularly from all the treatments. Percent infestation was calculated from hundred randomly selected plants. Statistical analysis was done following Gomez and Gomez (1984). 


\section{Results and Discussion}

Morphologically the full-grown larvae of leaf roller are light green in colour and $10-15 \mathrm{~mm}$ in length and 3-4 $\mathrm{mm}$ in breadth. Usually one larva can be found in one folded leaf. But sometimes 2-3 larvae are also observed within the same folded leaf. Leaf roller has six larval instars and the entire larval period of 12-15 days and the pupal period are spent within the folded leaves. Leaf roller was found to infest the soybean crops in the 3rd week of January during the vegetative and flowering stages (45-60 days after sowing = DAS) of the crop, and continued up to pre-maturity (80-85 DAS) (Fig.1). The highest leaf roller incidence ( $0.9 \&$ 1.0/plant) was recorded in the 3rd week of February at the pod formation stage of the crop (65-70 DAS) (Fig.1). In 2008, the highest leaf roller infestation of $90 \%$ plant and $50 \%$ leaf was recorded in the 3rd week of February at the pod formation stage of the crop (65-70 DAS) and then declined gradually (Fig. 2). Similarly in 2009, the highest leaf roller infestation of 95\% plant and $60 \%$ leaf was recorded in the 3rd week of February at the pod formation stage of the crop (65-70 DAS), and then declined gradually (Figs. 2). In 2009, leaf roller incidence and their infestation were observed slightly higher than that of 2008 (Figs. 2 and 3). Gangwar and Thakur (1988) reported that the pest infested about $70-90 \%$ soybean plants which resulted in $22 \%$ loss of yield in India.

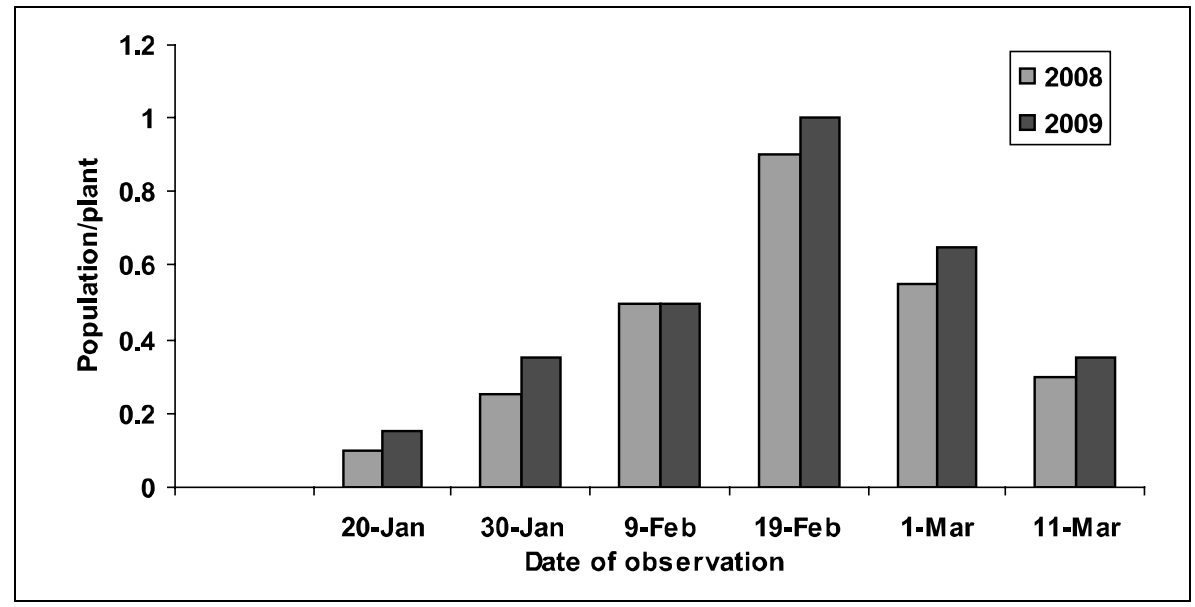

Fig. 1. Incidence of leaf roller in soybean plant during 2008 and 2009 at Gazipur.

Among the treatments, the mechanical destruction by hand picking + neem seed kernel extract reduced the highest plant (93.31\%) and leaf (90.43\%) infestation followed by hand picking technique and Diazinon 60EC treated plots over the untreated (Table 1). All the treatments significantly reduced the leaf roller infestation over the untreated. Significantly higher seed yield $(1300 \mathrm{~kg} / \mathrm{ha})$ was obtained from Diazinon 60 EC treated plot followed by hand picking+Neem 
seed kernel extract treated plots $(1280 \mathrm{~kg} / \mathrm{ha})$. The highest benefit cost ratio (BCR) was 3.00 was observed from the hand picking treatment, plot followed by Diazinon 60 EC sprayed plots (2.66)(Table 2). Neem seed kernel extract reduced about $83 \%$ plant and $77 \%$ leaf infestation. Although chemical insecticides treated plots produced higher yield than other treatments, but they poses to cause environmental pollution and health hazards compared to mechanical technique and application of botanicals. So, collection by hand picking of the infested leaves with larvae and spraying of neem seed kernel extract can be considered an effective, eco-friendly management of leaf roller in soybean crop.

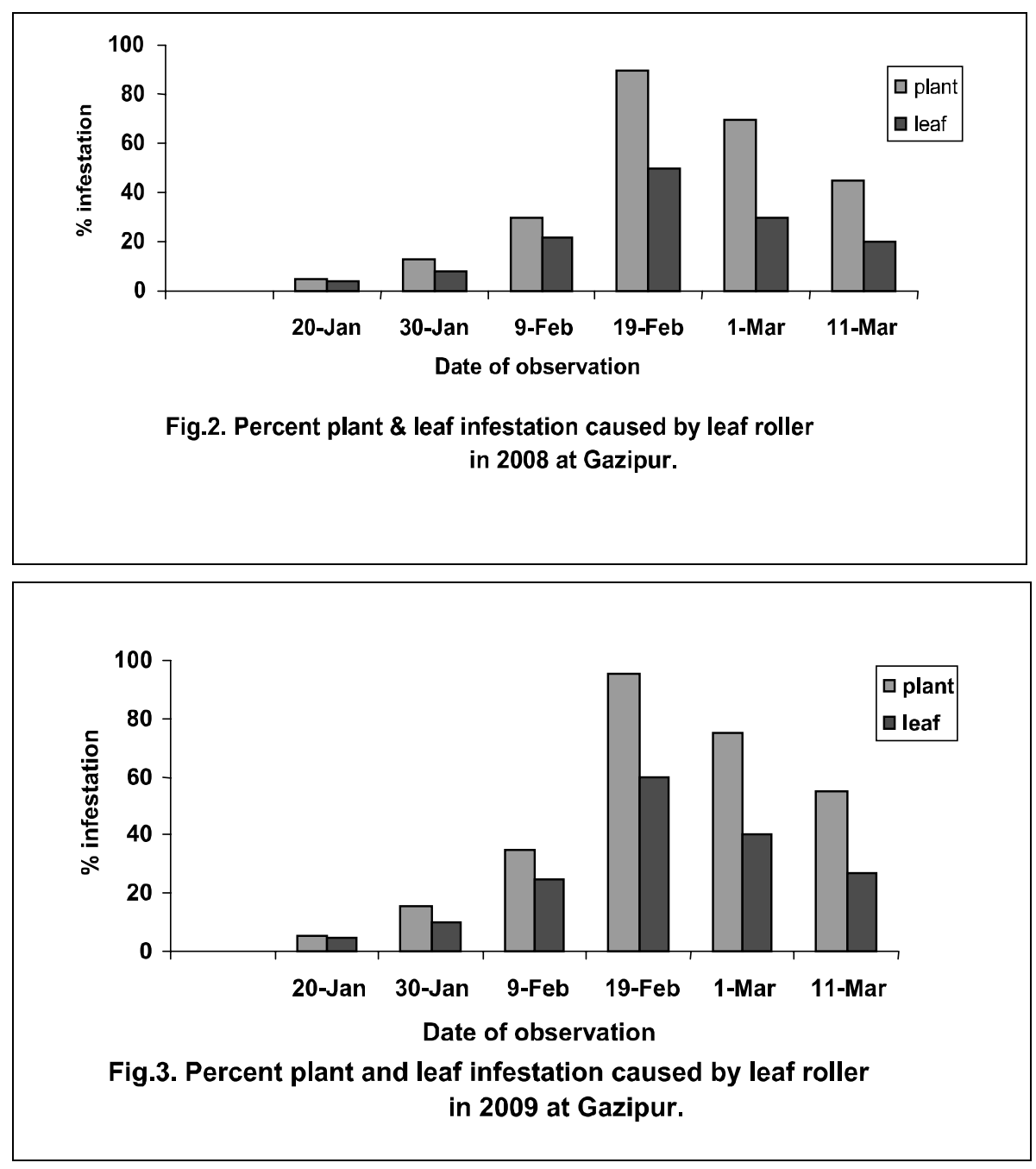


Table 1. Efficacy of different treatments against leaf roller of soybean in pooled data of 2008 and 2009 at BARI Farm, Gazipur

\begin{tabular}{|c|c|c|c|c|c|}
\hline Treatment & $\begin{array}{c}\text { Percent } \\
\text { plant } \\
\text { infestation }\end{array}$ & $\begin{array}{l}\text { Percent plant } \\
\text { infestation } \\
\text { reduction over } \\
\text { untreated }\end{array}$ & $\begin{array}{c}\text { Percent } \\
\text { leaf } \\
\text { infestation }\end{array}$ & $\begin{array}{l}\text { Percent leaf } \\
\text { infestation } \\
\text { reduction } \\
\text { over } \\
\text { untreated }\end{array}$ & $\begin{array}{l}\text { Yield } \\
\text { (kg/ha) }\end{array}$ \\
\hline Handpicking (HP) & $6.25 \mathrm{~d}$ & 90.48 & $4.45 \mathrm{~d}$ & 92.00 & 1150 bc \\
\hline $\begin{array}{l}\text { Neem seed } \\
\text { extract(NSE) }\end{array}$ & $10.55 \mathrm{~b}$ & 83.93 & $12.67 \mathrm{~b}$ & 77.24 & 1100 bc \\
\hline $\mathrm{HP}+\mathrm{NSE}$ & $4.33 \mathrm{bc}$ & 93.31 & $5.33 \mathrm{bc}$ & 90.43 & 1280 a \\
\hline Diazinon 60EC & $6.67 \mathrm{bc}$ & 89.84 & 8.47 bc & 84.78 & 1300 a \\
\hline Dursban 20EC & $7.33 \mathrm{bc}$ & 88.84 & $9.87 \mathrm{bc}$ & 82.27 & $1200 \mathrm{~b}$ \\
\hline Perfecthion 40EC & $8.67 \mathrm{bc}$ & 86.80 & $10.25 \mathrm{~b}$ & 81.58 & $1240 \mathrm{ab}$ \\
\hline Untreated & $65.67 \mathrm{a}$ & - & $55.67 \mathrm{a}$ & - & $750 \mathrm{~d}$ \\
\hline
\end{tabular}

Table 2. Economics of different treatments applied against leaf roller in soybean in pooled data of 2008 \& 2009 at BARI Farm, Gazipur

\begin{tabular}{|c|c|c|c|c|c|c|}
\hline Treatments & $\begin{array}{c}\text { Yield } \\
\text { (kg/ha) }\end{array}$ & $\begin{array}{c}\text { Increased } \\
\text { yield over } \\
\text { Untreated } \\
\text { (kg/ha) }\end{array}$ & $\begin{array}{c}\text { Additional } \\
\text { income } \\
\text { (Tk./ha) }\end{array}$ & $\begin{array}{c}\text { Cost of } \\
\text { insecticid } \\
\text { s \& spray } \\
\text { (Tk./ha) }\end{array}$ & $\begin{array}{c}\text { Net } \\
\text { income } \\
\text { (Tk./ha) }\end{array}$ & MBCR \\
\hline Handpicking (HP) & 1150 bc & 400 & 12000 & 3000 & 9000 & 3.00 \\
\hline $\begin{array}{l}\text { Neem seed extract } \\
\text { (NSE) }\end{array}$ & 1100 bc & 350 & 10500 & 3400 & 7100 & 2.08 \\
\hline $\mathrm{HP}+\mathrm{NSKE}$ & $1280 \mathrm{a}$ & 530 & 15900 & 4500 & 10400 & 2.53 \\
\hline Diazinon & $1300 \mathrm{a}$ & 550 & 16500 & 4500 & 12000 & 2.66 \\
\hline Dursban & $1200 \mathrm{~b}$ & 450 & 13500 & 3600 & 9900 & 2.75 \\
\hline Perfecthion & $1240 \mathrm{ab}$ & 490 & 14700 & 4000 & 10700 & 2.67 \\
\hline Untreated & $750 \mathrm{~d}$ & - & - & - & - & - \\
\hline
\end{tabular}

MBCR $=$ Net income/management cost

Notes: Cost of Neem seed $=50 \mathrm{Tk} / \mathrm{kg}$, Cost of Perfecthion $50 \mathrm{EC}=1100 \mathrm{TK} . /$ litre, Cost of Diazinon=1200 Tk./litre. Dursban $20 \mathrm{EC}=780 \mathrm{Tk} / \mathrm{litre}$, Price of soybean seed $=30 \mathrm{Tk} . / \mathrm{kg}$, Cost of labour=150 Tk./labour/day 3 labours and 1 litre of Diazinon 60 EC @ $2 \mathrm{ml} / \mathrm{I}$ being required for 1 hectare of crop field sprayed once. Ten labours required for collection of infested leaf/day/ha. BCR= Net income/ management cost. One machine spray volume $=10$ litre required $200 \mathrm{sqm}$ field spraying once. Other variable costs were same in all the treatments.

The observations of the present study were similar to the findings of several authors. Morde and Blackwell (1993) reported that azadirachtin present in neem 
product acts as an antifeedant and growth regulators on many insect pests in India. Senthil et al. (1997) tested efficacy of neem products on antifeedant, growth inhibitory and ovipositional repellency to Spodoptera litura. They observed that a significant increase in the larval mortality, antifeedancy and ovipositional repellency were found after treatment with neem formulations.

\section{Conclusion}

The present study showed that the soybean crop suffered maximum leaf roller infestation during the last week of February at pod formation stage. Mechanical destruction of the larvae i.e. hand picking of the infested leaves with larvae of leaf roller and spraying of neem seed kernel extract were ecologically safe and very effective in controlling the pest in soybean crop. Among the insecticides, Diazinon60 EC @ 2ml/l of water reduced the highest leaf roller infestation (about 90.00\%) and produced the highest yield (1300 kg/ha). However, the highest BCR (3.00) was obtained from the treatment that received hand picking technique.

\section{References}

Anonymous. 2009. Research Report on Oilseed Crops. Oilseed Research Centre, BARI, Gazipur. pp.238.

Biswas, G.C., M.M. Hossain and U.K. Majumder. 2001. Screening of some soybean entries against leaf roller (Lamprosema indicata F.). Bangladesh J. Agril. Res. 26 (2): 295-300.

Biswas, G.C. 2001. Screening of some soybean entries for resistance to stem flies (Ophiomyia phaseoli Tryon and Melanagromyza sojae Zehntner) and their incidence. J. Asiat. Soc. Bangladesh Sci. 27 (1): 93-100.

Biswas. G.C. 2008. Insect pests and their management of soybean crop in Bangladesh. Proceedings of the Workshop on Prospects and Performance of Soybean in Bangladesh (M. A. Bakr ed.) ORC, BARI, Gazipur. pp.67.

Das, G.P. 1998. Major Insect and Mite Pests of Important Crops and Stored Products of Bangladesh. Bangladesh Agricultural Research Institute, Joydebpur, Gazipur-1701. pp. 102.

Fehr, W.R. 1989. Soybean, importance and distribution. pp. 283-300. In: Robblen, G.R.K. Downy and Ashri (ed). Oilcrops of the World. Mc-Graw-Hill. Pub. Com. New York.

Gangwar, S.K. and A.N.S. Thakur. 1988. Population level of leaf roller in soybean in East Khasi Hill. National Symposium on insect pest and diseases of soybean 1-3 Nov. R.A.K. College of Agric. Sehore: 15.

Gomez, K.A. and A.A. Gomez, 1984. Statistical Procedure for Agricultural Research. John Willy and Sons. New York. pp. 680. 
Haque, M.A. and B.N. Islam. 1988. Effect of methanolic neem and chinaberry seeds extract on rice green leaf hopper, Nephotettix nigropictus. Bangladesh J. of Agril. 13 (10: 53-57.

McIntyre, A. N., H. Allison and D. R. Pebnab. 1989. Pesticides: Issues and options for New Zealand. Ministry of Environment, Wellington, New Zealand. pp. 168.

Morde, A.J. and K. Blackwell.1993. Azadiractin: an update. J. Insect Physiol. 39(11): 903-924.

Nair, M.R.G.K. 1986. Insects and Mites of crops in India. Allied Publishers, ICAR, New Delhi, India. pp.408

Sachan, J.N. and S. K. Gangwar. 1980. Insect pests of soybean in Khasi Hills of Meghalaya and their control. Bull Ent. 21(1-2): 105-112.

Sarode, S.V., R.O. Deotale and H.S. Thakure. 1995. Evaluation of neem seed kernel extract for the management of Helicoverpa armigera on pegion pea. Indian J. Ent. 57(4) :385-388.

Saxena, R.C., N.S. Liquido. and H.D. Justo. 1981. Neem oil a potential antifeedant for the control of brown plant hopper, Nilapatvata lugens. Proc. 1st Int. Neem Conf. Rootach, June, 1980.Egern. pp.171-188.

Senthil, N. K., D. Jeyabalan and K. Murugan. 1997. Antifeeding and growth inhibiting effect of neem leaf exudates on Spodoptera litura . Indian J. Ent. I59 (2): 151-154. 